\title{
Un Hellène chez les Latins : Georges Gémiste Pléthon
}

\section{Yves Hersant}

\section{(2) OpenEdition}

Journals

Édition électronique

URL : http://journals.openedition.org/etudesbalkaniques/405

ISSN : 2102-5525

\section{Éditeur}

Association Pierre Belon

\section{Édition imprimée}

Date de publication : 1 janvier 1999

Pagination : 121-130

ISBN : 2-910860-09-4

ISSN : $1260-2116$

\section{Référence électronique}

Yves Hersant, « Un Hellène chez les Latins : Georges Gémiste Pléthon », Études balkaniques [En ligne], 6 | 1999, mis en ligne le 08 avril 2009, consulté le 01 mai 2019. URL : http://journals.openedition.org/ etudesbalkaniques/405

Ce document a été généré automatiquement le 1 mai 2019.

Tous droits réservés 


\title{
Un Hellène chez les Latins : Georges Gémiste Pléthon
}

\author{
Yves Hersant
}

AUTEUR

YVES HERSANT

E.H.E.S.S.-Paris, Centre d'études sur l'Europe 